\title{
Isolation of Protease Producing Bacteria from Soil and Characterization of the Protease
}

\author{
Ankita Chakraborty and Srabani Karmakar* \\ Department of Biotechnology, Techno India University, West Bengal, \\ EM4/1, Sector V, Salt Lake, Kolkata 700064, India \\ *Corresponding author
}

\section{Keywords}

Biotechnological,

Proteases,

Proteolytic, colony bacteria

Article Info

Accepted:

25 February 2020

Available Online: 10 March 2020

\section{A B S T R A C T}

Microbes are famous source of industrially important enzymes which can easily be modified by biotechnological methods. Proteases are group of commercially important enzymes which can cleave proteins into smaller fragments. This enzymes are widely used at an industrial scale for processing of various foods, cheese production, in leather industry etc. Proteases also serve as signalling molecules. Soil is a rich and biodiverse source of a huge number of microorganisms. The present study is based on the characterization of the protease producing bacteria from the soil present outside and adjacent areas of a sweetshop in Burdwan. Screening of the bacteria was done by employing skim milk agar plating technique at $37^{\circ} \mathrm{C}$ and observed after 24 hours. Proteolytic activity of the crude protease extract from the bacteria was detected by using azocasein as substrate. Two bacteria was initially screened; one was giving white colony and the other was giving yellow colony. White colony bacteria showed to give higher activity. The optimum $\mathrm{pH}$ for the protease activity was found to be 8.5 for both bacteriabut the optimum temperature was $37^{\circ} \mathrm{C}$ for yellow and $60^{\circ} \mathrm{C}$ for white. Bacteria isolated were coccus shaped and Gram-positive in nature. The isolated white bacteria was identified by 16s rDNA sequencing as Staphylococcus species.

\section{Introduction}

Enzymes are the biological catalysts that function to enhance the metabolic rate of reactions (1). They have wide range of industrial applications for multiple purposes like organic synthesis, chemical synthesis, detergents, food production, pharmaceuticals and fermentation $(2,3,4)$. Proteases are a group of enzyme involved in digesting protein chains into short peptides and finally splitting them further into amino acid residues by breaking the peptide bonds between them $(5,6,7)$. These are ubiquitous in nature and are produced by all living organisms starting from plants, animals and all forms of microbes such as algae, fungi, molds and bacteria mainly Staphylococcus, Bacillus, 
Pseudomonas, Helomonas, Arthrobacter and many more. Some of the proteases attack the terminal amino acids from the protein chain and therefore are called as exopeptidase (such as amino acid peptidase, Carboxypeptidase A) and others attack internal peptide bonds and thus are called endopeptidase (such as trypsin, chymotrypsin, pepsin, papain and elastin).

Proteases can be used effectively for the degradation of protein containing wastes, to remove clogs from drainage pipes and thus considered as "biocleaner" $(8,9,10,16)$. Proteases have many physiological and pathological roles such as protein catabolism, blood coagulation, tissue rearrangement, cell growth and migration, tumor growth, morphogenesis in development, transport of secretory proteins across the membranes, activation of zymogens $(14,15)$.

Protease containing subtilisin group are used in the treatment of burns and wounds, oral administration produces an anti-inflammatory response in burnt patients and speeds up the process of healing $(11,12)$. Protease enzymes can produce eco-friendly products and so they have wide application in biotechnological industries $(1,19)$. . Proteases are extracted commercially from different plants, animals and microbial sources. The most easily available source is the microbial production of proteases.

They are very easily grown and can be manipulated by the application of genetic engineering. $60 \%$ of the total enzyme market is been shared by the enzyme produced by the bacteria. Protease production by microorganisms is greatly influenced by media components like nitrogen and carbon sources and by physical factors such as $\mathrm{pH}$, temperature, agitation, inoculum density and incubation time $(2,20)$. Microbial enzyme production on an industrial scale was $1 \mathrm{st}$ started by Takamine, in 1980, he started the production of Takadiastase enzyme which was actually $\alpha$-amylase that contained substantial amount of proteases $(2,21)$. Since then many kind of protease production took place in the market.

Among the variety of different microorganisms Bacillus sp. was known to produce maximum amount of protease commercially $(2,22)$. Our study was aimed at finding new strains of microorganisms producing proteases in the soil. We have screened two bacteria for protease property and identified one bacterium by $16 \mathrm{~s}$ rDNA sequencing method as Staphylococcus species.

\section{Materials and Methods}

\section{Soil sample}

Soil sample was collected from near and adjacent areas of a sweet shop in Burdwan District, West Bengal, in a sterilized bag and carried to the laboratory for further analysis.

\section{Isolation and screening of bacteria}

$1 \mathrm{gm}$ of the soil sample was weighed and serially diluted $\left(10^{\wedge}-1\right.$ to $\left.10^{\wedge}-6\right) .0 .1 \mathrm{ml}$ of the aliquots were spread plated on Skimmed Milk Agar and incubated 24 hours at $37^{\circ} \mathrm{C}$. Caseinolytic activity of the bacteria was noted by the hydrolytic zones formed on the plates. Colonies showing higher zones were streak plated on Nutrient Agar which were stored at $4^{\circ} \mathrm{C}$ for further studies.

\section{Cell lysate preparation}

Bacteria was grown in Nutrient broth which was centrifuged at $6000 \mathrm{rpm}$ for $10 \mathrm{mins}$. The pellet was dissolved in $200 \mathrm{mM}$ lysis buffer (containing TRIS-Cl and EDTA; $\mathrm{pH}=8$ ), lysozyme $(20 \mathrm{mg} / \mathrm{ml})$ and protease inhibitor cocktail and incubated for 1 hour at $37^{\circ} \mathrm{C}$. 


\section{Partial purification of crude enzyme}

Partial purification of the enzyme by Zambare method in which the cell lysate was precipitated with ammonium sulfate(at $40 \%$ saturation) and at 5000rpm for 20 minutes at $4^{\circ} \mathrm{C}$. After the centrifugation was done, the protease precipitate was loaded in dialysis bag for dialysis which was dipped in $100 \mathrm{ml}$ of $200 \mathrm{mM}$ phosphate buffer $(\mathrm{pH}=8)$ for 6 hours with a change of buffer after every 2 hours. After this the partially purified protease was collected and protease activity and also its molecular weight was determined.

\section{Estimation of protein concentration by Lowry's method}

Unknown samples were incubated with TRIS$\mathrm{Cl}$ buffer, Reagent $\mathrm{A}(2 \%$ of sodium carbonate mixed with $0.1 \mathrm{~N}$ sodium hydroxide), Reagent B (1. 56\% Copper sulfate with mixed 2. $37 \%$ sodium potassium tartrate) and $2 \mathrm{ml}$ Folin-Ciocalteau reagent in dark for 30 minutes and the amount of the tyrosine released was measured calorimetrically at $660 \mathrm{~nm}$.

\section{Estimation of protease activity by using azocasein as substrate}

Enzyme activity was determined by using azocasein as substrate. Protease activity of the cell lysate or extract after ammonium sulphate precipitation was measured by azocasein assay (degradation of azo group from azocasein in per unit time can be detected by monitoring absorbance at $405 \mathrm{~nm}$ ). $0.1 \mathrm{ml}$ of the crude enzyme was incubated with $0.25 \mathrm{ml}$ of azocasein (2\% azocasein in $0.1 \mathrm{M}$ Tris HClbuffer; $\mathrm{pH}=7$ ) for $60 \mathrm{mins}$ at $37^{\circ} \mathrm{C}$ and the reaction was stopped by the addition of $0.2 \mathrm{ml}$ of $\operatorname{TCA}(5 \%)$.

\section{Effect of pH on protease activity}

To study the effect of $\mathrm{pH}$ the azocasein assay was carried out by changing the $\mathrm{pH}$ of the reaction $(\mathrm{pH}=4,5,6,7,7.5,8,8.5,10)$ and incubating at $37^{\circ} \mathrm{C}$. The absorbance value was converted to enzyme activity in terms of degradation of azo dye per unit time per unit protein with the help of extinction coefficient of azocasein 37 litres g-1 and cm-1.

\section{Effect of temperature on protease activity}

To study the effect of temperature the azocasein assay was carried out at different temperature $\left(4^{\circ} \mathrm{C}, 25^{\circ} \mathrm{C}, 37^{\circ} \mathrm{C}, 55^{\circ} \mathrm{C}, 80^{\circ} \mathrm{C}\right)$ at a constant $\mathrm{pH}$ 7. 0. Enzyme activity was calculated as earlier.

\section{SDS PAGE of the protein extract from bacterial lysate}

Molecular weight of the protease was determined by SDS-PAGE in which $15 \%$ gel (Resolving and Stacking gel) is prepared as per the Lammeli method,1970 (4,30). After running the electrophoresis the gel was stained with 0. 1\% Coomassie Brilliant Blue, protein band was visualized after de-staining with methanol, acetic acid and water in the ratio of $4: 1: 5$. The molecular weight of the partially purified protease was estimated by using standard protein marker of known molecular weight.

Genomic DNA isolation and PCR amplification of 16s rDNA

Genomic DNA was isolated by phenolchloroform extraction method(30) and then agarose gel electrophoresis was carried out, the DNA bands were then visualized by GelDocumentation System. They were then amplified by universal primers $27 \mathrm{~F}$ and 1492R.

\section{Sequencing of $16 \mathrm{~s}$ rDNA and BLAST analysis}

$16 \mathrm{~S}$ rDNA sequencing was performed in 
order to identify the unknown bacterial isolate. $16 \mathrm{~S}$ rDNA sequencing was outsourced from eurofins technologies for species identification. NCBI website is used to perform BLASTn against $16 \mathrm{~s}$ rDNA database for prokaryotes.

\section{Molecular phylogenetic analysis}

The top 10 sequences from the BLASTn result was obtained and used for phylogenetic tree formation. Phylogenetic tree was obtained by using phylogeny. fr website following the neighborhood joining method.

\section{Results and Discussion}

\section{Isolation and screening of bacteria}

Two strains of bacteria were screened among others which showed clear zones on the Skimmed Milk Agar plate indicating caseinolytic property of proteases (Figure 1).

These two strains were isolated and allowed to grow on nutrient agar media. Pure colonies were obtained with distinct morphological features.

\section{Characterization of bacteria}

After sub-culturing on the Nutrient agar plates from the milk agar plates by streak plate method, the following characteristics of the colonies were observed in Figure 2 and table 1 .

\section{Protein concentration of bacterial extract}

White and Yellow both bacterial cell lysates showed high protein concentration as determined by Lowry's method using BSA standard curve.

Figure 3 showed that white bacterial lysate has $1.49 \mathrm{mg} / \mathrm{ml}$ and yellow bacterial colony has $1.28 \mathrm{mg} / \mathrm{ml}$ protein.
Determination of protease activity by using azocasein as substrate

Estimation of the protease activity was estimated quantitatively by using azocasein substrate. Degradation of azo dye was measured by absorbance at 440nm.

From the equation, enzyme activity was determined:-

Enzyme activity $=(\Delta$ Absorbance $/ \mathrm{min}) /$. ( $C$ is the molar extinction coefficient and $\mathrm{E} 1 \%$ of azocasein is 37 litres $\mathrm{g}-1$ and $\mathrm{cm}-1$

\section{Effect of pH on protease activity}

A standard protease assay using azocasein was carried out by varying $\mathrm{pH}(4-10)$ for 1 hour at $37^{\circ} \mathrm{C}$. The optimum $\mathrm{pH}$ of the protease enzyme was found to be 8. 5 . Protease from white bacteria showed higher activity (Figure 4).

\section{Effect of temperature on protease activity}

A standard protein assay using azocasein was carried out at constant $\mathrm{pH} 7$ for 1 hour by varying the temperatures $\left(4-80^{\circ} \mathrm{C}\right)$. The optimum temperature of the protease from yellow bacteria was found to be $37^{\circ} \mathrm{C}$. Protease from white bacteria showed optimum temperature at $60^{\circ} \mathrm{C}$ (Figure 5).

\section{SDS PAGE of bacterial cell lysate}

SDS PAGE image showed (Figure 6) protein bands in both the samples and the major bands were found to be around $63 \mathrm{kDa}$ and below 48kDa.

Genomic DNA of the two identified bacterial strains

Genomic DNA was clearly observed in $1 \%$ agarose gel (Figure 7). 
Table. 1 Colony morphology

\begin{tabular}{|c|c|}
\hline Color & Shape and Size \\
\hline White & Large and round \\
\hline Yellow & Small and round \\
\hline
\end{tabular}

Table.2 BLAST result for 16s rDNA sequence of the white bacteria

\begin{tabular}{|c|c|c|c|c|}
\hline Microbial Strain & Accession no & Query Value & E Value & Per. Ident \\
\hline $\begin{array}{l}\text { Staphylococcus pasteuri } \\
\text { strain ATCC } 51129\end{array}$ & NR_114435. 1 & $96 \%$ & 0 & $99.07 \%$ \\
\hline $\begin{array}{l}\text { Staphylococcus warneri } \\
\text { AW } 25\end{array}$ & NR_025922. 1 & $96 \%$ & 0 & $98.79 \%$ \\
\hline $\begin{array}{l}\text { Staphylococcus } \\
\text { lugdunesis strain ATCC } \\
43809\end{array}$ & NR_024668. 1 & $96 \%$ & 0 & $98.34 \%$ \\
\hline $\begin{array}{l}\text { Staphylococcus kloosii } \\
\text { strain ATCC } 43959\end{array}$ & NR_024667. 1 & $96 \%$ & 0 & $98.19 \%$ \\
\hline $\begin{array}{l}\text { Staphylococcus cohnii } \\
\text { subsp. Urealyticus strain } \\
\text { CK27 }\end{array}$ & NR_037046. 1 & $96 \%$ & 0 & $98.19 \%$ \\
\hline $\begin{array}{l}\text { Staphylococcus } \\
\text { gallinarum strain VIII1 }\end{array}$ & NR_036903. 1 & $96 \%$ & 0 & $98.19 \%$ \\
\hline $\begin{array}{l}\text { Staphylococcus } \\
\text { petrasiistrain CCM } 8418\end{array}$ & NR_118450. 1 & $96 \%$ & 0 & $98.19 \%$ \\
\hline $\begin{array}{l}\text { Staphylococcus } \\
\text { saprophyticus subsp. } \\
\text { saprophyticus }\end{array}$ & NR_074999. 2 & $96 \%$ & 0 & $98.04 \%$ \\
\hline $\begin{array}{l}\text { Staphylococcus } \\
\text { edaphicus strain CCM } \\
\mathbf{8 7 3 0}\end{array}$ & NR_156818. 1 & $96 \%$ & 0 & $98.04 \%$ \\
\hline $\begin{array}{l}\text { Staphylococcus } \\
\text { saprophyticus strain } \\
\text { NBRC } 102446\end{array}$ & NR_114090. 1 & $96 \%$ & 0 & $98.04 \%$ \\
\hline
\end{tabular}




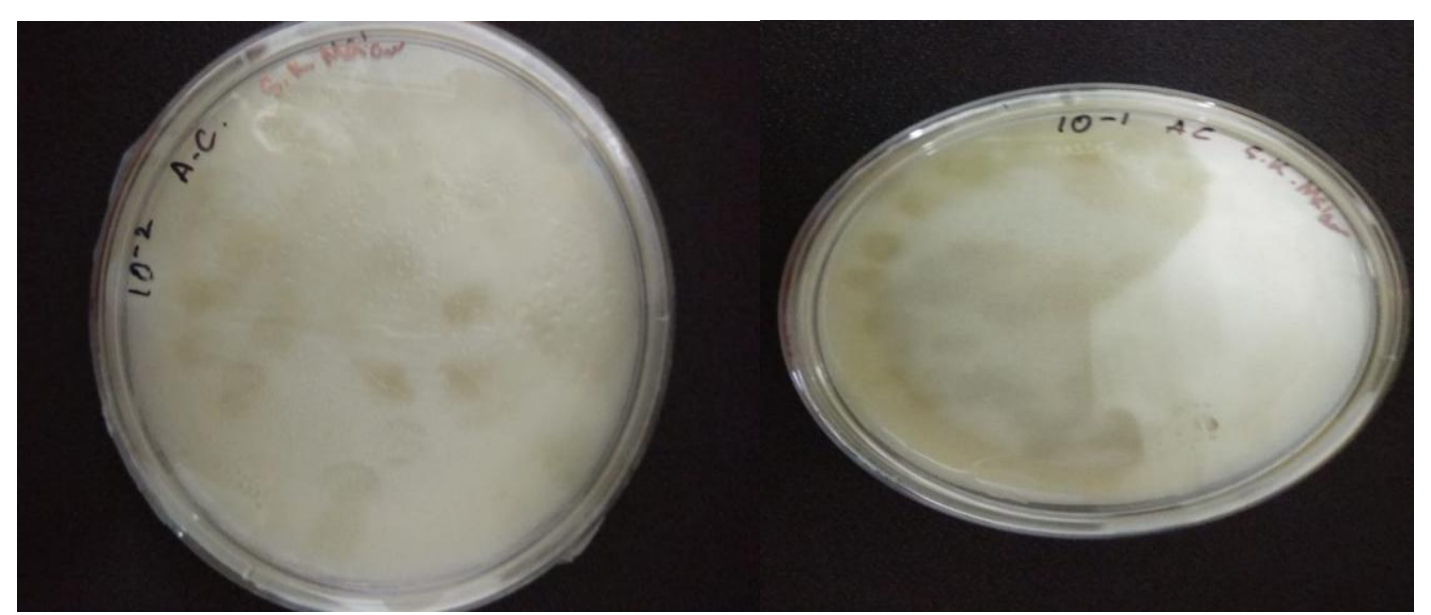

Figure.1 Screening of soil bacteria on skim milk agar plates showing casinolytic property

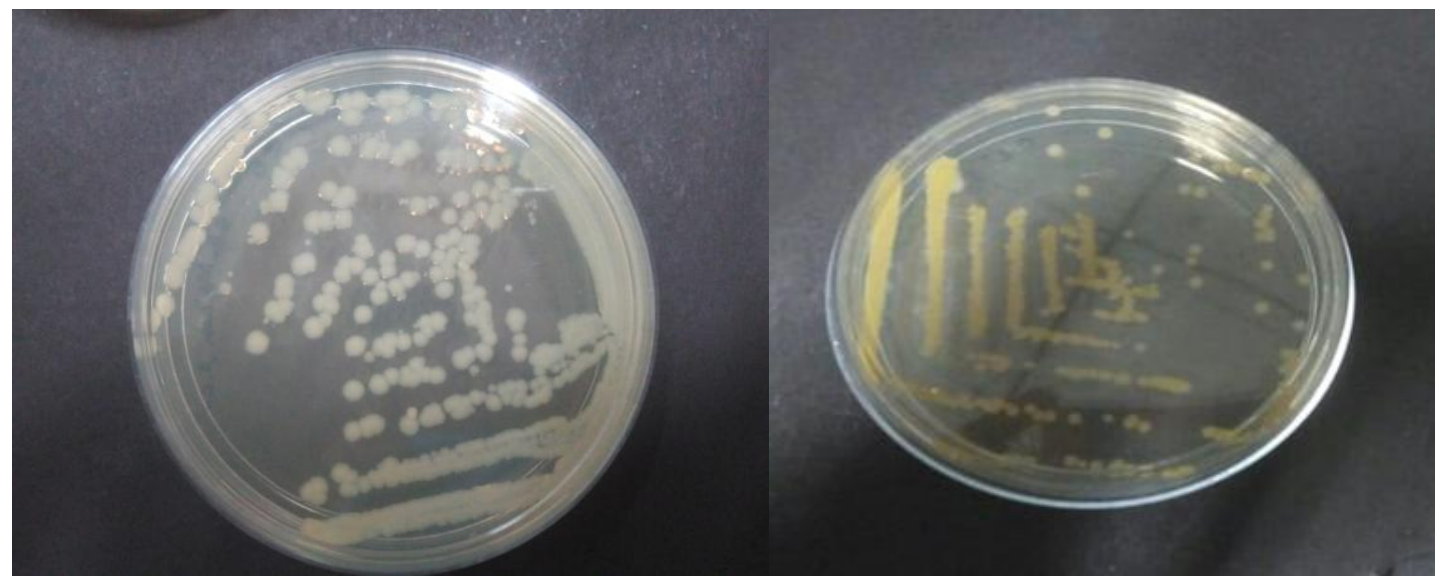

Figure.2 Single colony isolation on nutrient agar plates. A White colonies and B. Yellow colonies

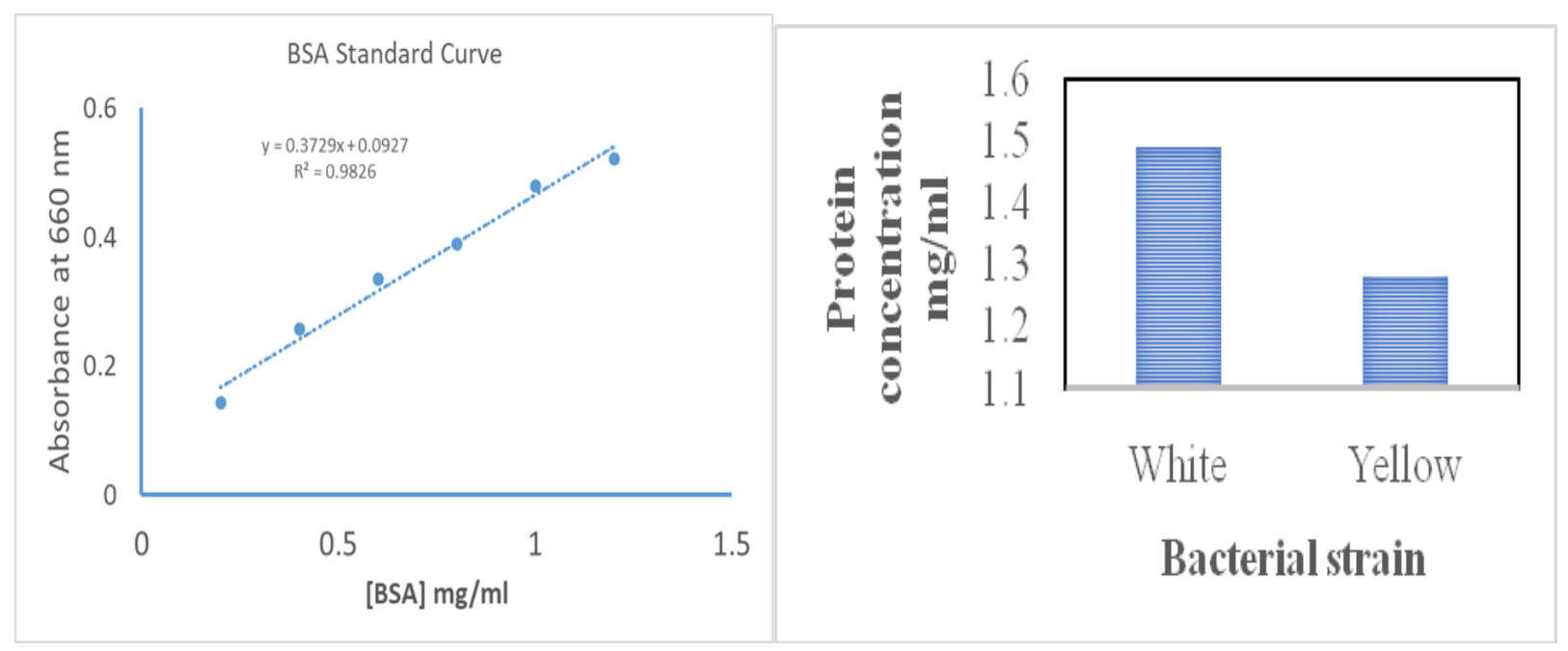

Figure.3 A. Standard curve of protein concentration using BSA as standard. B. Protein concentration in different crude extract 
Int. J. Curr. Microbiol. App. Sci (2020) 9(3): 2974-2983

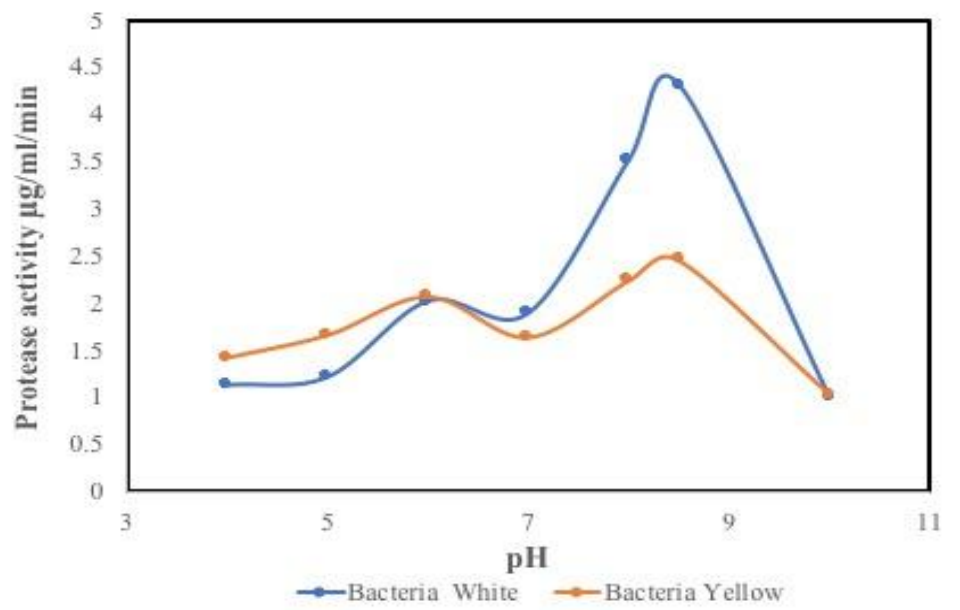

Figure.4 Characterization of protease activity with respect to $\mathrm{pH}$

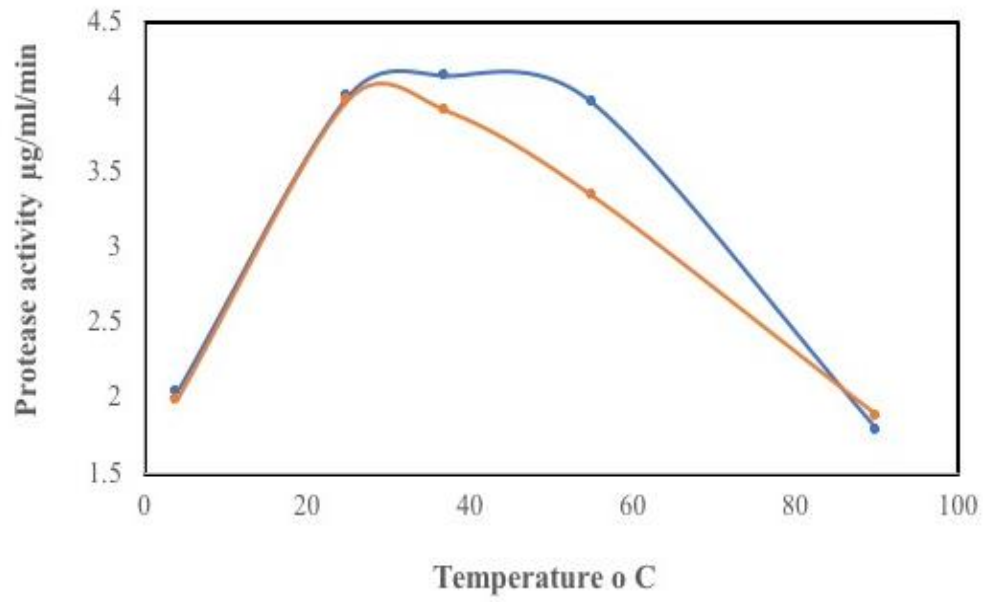

$\rightarrow$ Bacteria White $\rightarrow$ Bacteria Yellow

Figure.5 Characterization of protease activity with respect to temperature

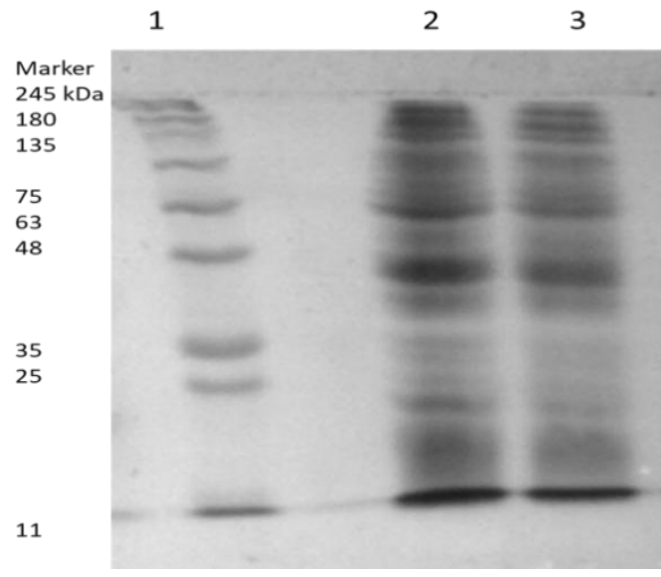

Figure.6 SDS PAGE showing protein bands in the crude cell lysate

$15 \%$ resolving gel showing lane 1 marker, lane 2 cell lysate from white bacteria and lane 3 cell lysate from yellow bacteria 


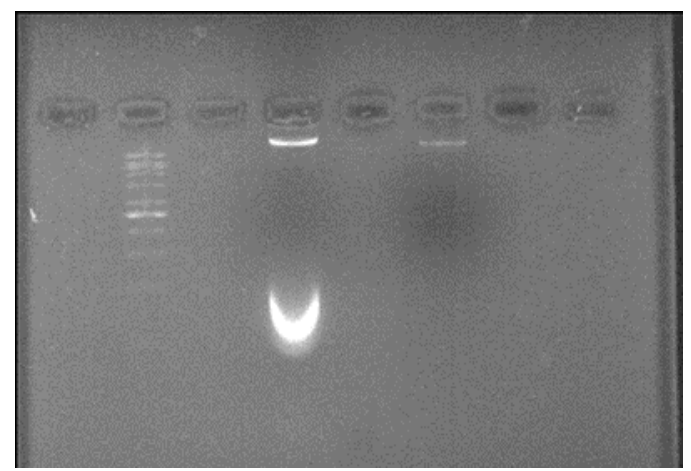

Figure.7 Genomic DNA observed in 1\% agarose gel

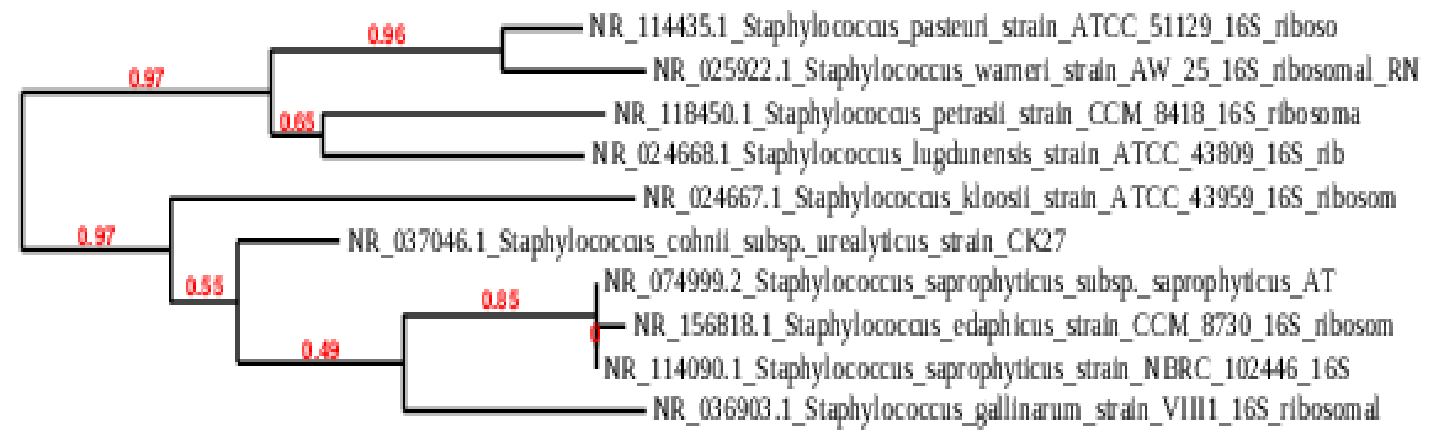

0.006

Figure.8 Phylogenetic tree showing the matches with high similarity in BLASTn result

\section{Sequencing of 16s rDNA and BLAST}

16S rDNA sequencing was outsourced from eurofins technologies for species identification. The obtained nucleotide sequence was used as query fordoing BLAST (Basic local alignment search tool) in NCBI website against 16s rDNA nucleotide database for prokaryotes. It was identified that the present study was with bacteria Staphylococcus and the highest degree of homology was identified and listed (Table 2).

The analysis suggested that the protease producing bacteria shared 99\% sequence similarity with 16SrDNA sequence of Staphylococcus pasteuri strain ATCC 51129 (NR_114435. 1). The strain shared 98. 79\% sequence similarity with Staphylococcus warneri AW 25 (NR_025922. 1); 98. 34\% sequence similarity with $16 \mathrm{~S}$ rDNA sequence of Staphylococcus lugdunesis strain ATCC
43809(NR_024668. 1); 98. 19\% sequence similarity with 16SrDNA sequence of Staphylococcus kloosii strain ATCC 43959(NR_024667. 1), Staphyloccocus cohnii subsp. urealyticus strain CK27(NR_037046. 1), Staphylococcus gallinarum strain VIII1 (NR_036903. 1) and Staphylococcus petrasii strain CCM 8418(NR_118450. 1);98. 04\% similarity with Staphylococcus saprophyticus subsp. saprophyticus ATCC 15305(NR_074999.2)

\section{Molecular phylogenetic analysis}

Top 10 sequences are downloaded in fasta format. These sequences were used to do multiple sequence alignment and phylogenetic tree construction with the help of phylogeny. fr website. The phylogenetic tree was shown in Figure 8.

Two bacteria strains from the soil of adjacent 
areas of a sweet shop are identified as protease producing bacteria. One of them is identified as Staphylococcus sp. The two proteases are highly active against azocasein at alkaline $\mathrm{pH}$ and at elevated temperature. They can be further explored.

\section{Acknowledgement}

We would like to acknowledge Techno India University and SERB TARE scheme for support.

\section{References}

1.Vishnu Priya V G, Preethi S, Karthikeyan S and Ramesh Babu N G, Isolation and Identification of Protease Producing Bacteria from Soil, International Research Journal of Engineering and Technology (IRJET) e-ISSN: 2395 -0056 Volume: 03 Issue: 08 | Aug-2016

2.Prakash Bhuyar,Isolation, Partial Purification and Characterization of Protease Enzyme from Proteolytic Bacteria from Dairy Soil, International Journal for Research in Applied Science \& Engineering Technology (IJRASET), Volume 5 Issue XI November 2017, 2321-9653

3. D. J. Mukesh Kumar et al. , Isolation and Characterization of Galactosidase Producing Bacillus sp. from Dairy Effluent, World Applied Sciences Journal 17 (11): 1466-1474, 2012

4.M Kumara Swamy, K M Sudipta, K C Rohit, B Purushatham, Rudramurthy G R, Isolation, screening and optimization of factors effecting protease production from Comomonaskerstersii KSM7, International Journal of PharmTech Research CODEN (USA): IJPRIF ISSN :0974-4304; Vol. 6, No. 2, pp 858-867, April-June 2014

5.W. Sidler and H. Zuber, Isolation and characterization of phycoerythrocyanin and chromatic adaptation of the thermophilic cyanobacterium Mastigocladus laminosus, Arch Microbiol (1981) 129: 268- 274

6.S. K. Purva, L. K. Gupta and J. K. Gupta, S. K. Purva, Thermostable alkaline protease from alkalophilic Bacillus sp. LS-3. Ind. J. Microbial. ,1998

7.Padma Singh, Anchal Rani, Neha Choudhary, Isolation and characterization of protease

producing Bacillus sp from soil, International Journal of Pharma Sciences and Research (IJPSR) Vol 6 No 04 Apr 2015ISSN : 0975-9492,

8.Kumar and Takagi,Microbial alkaline proteases: from a bioindustrial viewpoint, Biotechnol Adv. 1999 Dec 15;17(7):561-94

9.Gupta et al. , beta-Tubulin C354 mutations that severely decrease microtubule dynamics do not prevent nuclear migration in yeast. MolBiol Cell 13(8):2919-32, 2002

10.Imran Shah, Nasir Azam, Ghiasud Din, Nourin Ali, Waheedullah, Muhammad Qarim, Aamir Shehzad and Noor Muhammad, Isolation and Characterization of Protease Producing Bacteria from Soil, Journal of Bio-Molecular Sciences (JBMS) (2014) 2(1): 1-5.

11.Thangam et al. , Purification and characterization of alkaline protease from Alcaligenes faecalis, Biotechnology and Applied Biochemistry 35(Pt 2):149-54 . May 2002

12.Sidra Aftab, Samia Ahmed, Sadia Saeed and Sheikh Ajaz Rasool, Screening, Isolation and Characterization of alkaline protease producing bacteria from soil, Pakistan Journal for Biological Science 9(11) ;21222126, 2006

13.Prasad M. P,Molecular characterization of protease producing Bacillus sp. isolated from kitchen soil using RAPD markers, European Journal of Biotechnology and Bioscience 2014; 2 (3): 38-42

14.A. J. Barett,Families and clans of serine peptidases, Arch BiochemBiophys. 1995 Apr 20;318(2):247-50.

15.Amandeep Kaur, Seema Ahuja and Geetika Sharma, Isolation of Protease Producing Bacteria from Soil and Genomic Library Construction of Protease Gene, Journal of Chemical, Biological and Physical Sciences, November 2013 - January 2014, Vol. 4, No. 1; 216-219.

16.Kirti Jogdand, Deepali Suryawanshi, TejeswiniMunde and Savita Kate, Screening Of Protease Producer from Soil 
\& Its Application As A Bioclenar, IAETSD JOURNAL FOR ADVANCED RESEARCH IN APPLIED SCIENCES VOLUME 5, ISSUE 3, MAR/2018 ISSN NO: 2394-8442

17.Sandhya C, Sumantha A, Szakacs G, Pandey A,Comparative evolution of Neutral proteases production by Aspergillus oryzae in submerged and slid state-fermentation," Process Biochem. , 40, 2689-2694. 2005.

18.S. Sneha, Merina Paul Das and L. Jeyanthi, Isolation and screening of protease producing bacteria from marine waste, Journal of Chemical and Pharmaceutical Research, 2014, 6(5):1157-1159

19.Abebe Bizye, Abraham Sago,G, Admaru, H,Getachew, P Karsaand, M Amsaya, Isolation, optimization and characterization of protease producing bacteria from soil and water in Gondar town, North West Ethiopia, International Journal of Bacteriology, Virology and Immunology: Vol. 1(3): pp 020-024, May, 2005

21.C. Balachandran, Petroleum and polycyclic aromatic hydrocarbons (PAHs) degradation and naphthalene metabolism in Streptomyces sp. (ERI-CPDA-1) isolated from oil contaminated soil,Bioresource Technology, Volume-112,Pages- $\quad 83-90$ 2012

22Anustrup,Isolation, Identification and Characterization of Protease Producing Bacillus

spp. from Unexplored Ecosystems of IndoBurma Biodiversity Hotspots, International Journal for Current Microbiology and
Applied SciencesISSN: 2319-7706 Volume 4 Number 11 (2015) pp. 611-622,1980

23.Ferrero et al. , Thermostable alkaline proteases of Bacillus licheniformis MIR 29: isolation, production and characterization,Applied Microbiology and Biotechnology April 1996, Volume 45, Issue 3, pp 327-332

24.A AKembhavi, A Kulkarni, A Pant,Salttolerant and thermostable alkaline protease from Bacillus subtilis NCIM no. 64, ApplBiochemBiotechnol. 1993 JanFeb;38(1-2):83-92.

25.A Gessesse, B A Gashe, Production of alkaline protease by an alkalophilic bacteria isolated from an alkaline soda lake. Biotechnology Letters, 19, 479-481. doi:10. 1023/A:1018308513853,1997

26.I G Kumar, H Takagi, Microbial Proteases and Application as Laundry Detergent Additive,Volume 3 (12): 661-672, 2008

27.P L Manachini, M G Fortina,Lactobacillus helveticus heterogeneity in natural cheese starters: the diversity in phenotypic characteristics, ApplMicrobiol, Jan;84(1):72-80, 1998

28.B. Asha, M Palaniswamy, Optimization of alkaline protease production by Bacillus cereus FT 1 isolated from soil, Journal of Applied PharmaJ ;Pharmaceutical Science Vol. 8(02), pp 119-127, February, 2018

29.MitaVakilwala and Devyani Patel, Isolation and Screening of Protease Producing Organisms from Soil Sample, International Journal of Research and Scientific Innovation (IJRSI). Volume IV, Issue IV, April 2017.

\section{How to cite this article:}

Ankita Chakraborty and Srabani Karmakar. 2020. Isolation of Protease Producing Bacteria from Soil and Characterization of the Protease. Int. J. Curr. Microbiol. App. Sci. 9(03): 29742983. doi: https://doi.org/10.20546/ijcmas.2020.903.341 